\title{
Development of Improved Production Technology for Existing Rice-Maize Cropping System in Tungabhadra Command Area
}

\author{
Mallareddy*, B.K. Desai and B.G. Koppalkar \\ Department of Agronomy, UAS, Raichur-584 104 (Karnataka), India \\ *Corresponding author
}

\section{A B S T R A C T}

\section{Keywords}

Rice-Maize Cropping System

Article Info

Accepted:

12 January 2019

Available Online:

10 February 2019
Traditional agricultural practices have resulted in decreased soil fertility, shortage of water resources and deterioration of agricultural ecological environment, which are seriously affecting production of maize. A field experiment was conducted in medium black soil during kharif and rabi season of 2016-17 and 2017-18 at farmer field near Agricultural Research Station, Sirguppa. The results revealed that, among improved production technologies of maize, higher grain yield were noticed with improved method-4 $\left(\mathrm{T}_{5}: 7681\right.$ $\mathrm{kg} \mathrm{ha}{ }^{-1}$ ) over farmer method of cultivation $\left(\mathrm{T}_{1}: 5840 \mathrm{~kg} \mathrm{ha}^{-1}\right)$. The magnitude of improvement in grain yield of maize by improved method-4 (Minimum tillage, herbicide and $100 \%$ fertilizers application) was to the tune of 31.52 per cent over farmer method of cultivation. Improved production technology showed lower penetration resistance and higher soil moisture content as compared to existing rice-maize cropping system.

\section{Introduction}

Tungabhadra Project (TBP) and Upper Krishna Project (UKP) command areas are one of the major rice producing regions of Karnataka. Where about 5.78 lakh ha of rice is grown, which are referred to as rice bowl of Karnataka. Farmers of majority of command area do not go for second crop due to various reasons and spatial distribution of these "rice fallows" is not documented. In recent past much of this area has single crop per year, usually Kharif and no crop is grown during $\mathrm{rabi} / \mathrm{summer}$ up to the harvest of rice mainly due to lack of irrigation especially in tail end region. These rice fallows represents an enormous under used resources for crop diversification and increasing cropping intensity and production. Traditional low land rice grown with continuous flooding in Asia has relatively required high water input. Since, the rice is cultivated under continuously flooded ecosystem and it is associated with sequestration of $\mathrm{N}$ in resistant lignin compounds formed from the large amounts of retained crop residues. Thus, the farmers are facing difficulty in selection of a profitable sequence after paddy. Under such situations, there is ample scope for introduction of high valued arable crops and 
vegetables with the usage of conservation agricultural techniques or zero tillage technology which is popular in northern parts of our country.

In rice-maize cropping system farmers are practicing intensive tillage practices with higher dose of fertilizer's application. Another important consideration is poor plant stand of maize in rice fallows resulting in poor crop establishment, and above all, pitiable management of crop affects both biomass production and grain yield. These reasons could end up in realizing low crop yield and sometimes, returns were uneconomical as well and hence, low coverage of crops in rice fallows. Research evidence suggests that the crop residue retention/incorporation has favourable effect on soil properties (Praharaj et al., 2014). Thus, resource conservation technology (RCT) dealing with conservation of soil moisture, build up of organic matter and improvement in both soil structure and microbial population could be an appropriate approach to address these problems (Praharaj, 2013). In addition, if crop residues are retained on the soil surface in combination with suitable planting techniques, it may possibly alleviate terminal drought condition in pulses by conserving soil moisture and bring overall improvement in resource use and its optimum management. Hence, minimum soil traffic by adoption of appropriate technology involving no tillage and management of crop residues could lead to favourable effect on soil microbiological properties that would further enhance the overall resource use efficiency (RUE) and productivity capacity of rice fallows.

\section{Materials and Methods}

The experiment was conducted in farmer field near ARS, Siruguppa which is located at $76^{0} .54^{\prime \prime} \mathrm{E}$ Longitude, $15^{0} .38^{\prime \prime} \mathrm{N}$ Latitude and at an elevation of 380 meters from MSL located under Northern Dry Zone (Region II, Zone-3) of Karnataka with an average annual rainfall of $745.23 \mathrm{~mm}$ from July to October in about 42 rainy days. The experimental design was a laid out in randomized complete block design (RCBD) with 7 treatments [ $\mathrm{T}_{1:}$ Farmers method of cultivation, $\mathrm{T}_{2}$ : Improved method 1 (Zero till, herbicide and $75 \%$ fertilizers application) $\mathrm{T}_{3}$ : Improved method -2 (Zero till, herbicide and $100 \%$ fertilizers application) $\mathrm{T}_{4}$ : Improved method -3 (Minimum tillage, herbicide and 75\% fertilizers application) $\mathrm{T}_{5}$ : Improved method 4 (Minimum tillage, herbicide and 100\% fertilizers application)] with 4 replications. The gross plot size was $5.40 \mathrm{~m} \mathrm{X} 4.80 \mathrm{~m}$ and net plot size was $3.00 \mathrm{~m} \mathrm{X} 4.00 \mathrm{~m}$. The main objective is to increase maize yield in ricemaize cropping system by adopting improved production technologies like tillage management practices with judicious use of fertilisers and use of herbicides.

\section{Results and Discussion}

The data on plant height of maize differed significantly due to improved production technology. At 30 DAS, significantly higher plant height was recorded in improved method-4 treatment $\left(\mathrm{T}_{5}: 29.13\right.$ and $30.13 \mathrm{~cm}$, respectively) followed by improved method-3 $\left(\mathrm{T}_{4}: 27.15\right.$ and $28.15 \mathrm{~cm}$, respectively) and it was on par with improved method-2 ( $\mathrm{T}_{3}: 27.11$ and $28.11 \mathrm{~cm}$, respectively) and significantly lower plant height were recorded in farmer method of cultivation $\left(\mathrm{T}_{1}: 22.38\right.$ and $23.38 \mathrm{~cm}$, respectively) in rabi season of 2016-17 and 2017-18.Significantly higher plant height was recorded at 60 DAS in improved method-4 treatment $\left(\mathrm{T}_{5}: 121.85\right.$ and $123.95 \mathrm{~cm}$, respectively) and it was on par with improved method-2 $\left(\mathrm{T}_{3}: 118.75\right.$ and $120.95 \mathrm{~cm}$, respectively) and lower plant height were noticed in farmer method of cultivation $\left(\mathrm{T}_{1}: 107.50\right.$ and $107.25 \mathrm{~cm}$, respectively) (Table 1-4). 
Table.1 Effect of improved production technology on plant height $(\mathrm{cm})$ of maize in rice-maize cropping system

\begin{tabular}{|c|c|c|c|c|c|c|c|c|c|c|c|c|}
\hline \multirow[t]{2}{*}{ Treatments } & \multicolumn{3}{|c|}{30 DAS } & \multicolumn{3}{|c|}{60 DAS } & \multicolumn{3}{|c|}{90 DAS } & \multicolumn{3}{|c|}{ At harvest } \\
\hline & 2016-17 & 2017-18 & Pooled & 2016-17 & 2017-18 & Pooled & 2016-17 & 2017-18 & Pooled & 2016-17 & 2017-18 & Pooled \\
\hline $\begin{array}{l}T_{1} \text { : Farmers method of } \\
\text { cultivation }\end{array}$ & 22.38 & 23.38 & 22.88 & 107.50 & 107.25 & 107.38 & 150.81 & 154.32 & 152.56 & 155.53 & 160.28 & 154.92 \\
\hline $\begin{array}{l}T_{2:} \text { Improved method -1 (Zero } \\
\text { till, herbicide and } 75 \% \\
\text { fertilizers application) }\end{array}$ & 25.55 & 26.55 & 26.05 & 116.65 & 118.85 & 117.75 & 163.35 & 169.88 & 166.61 & 168.33 & 173.43 & 169.10 \\
\hline $\begin{array}{l}\text { T}_{3:} \text { Improved method }-2 \\
\text { (Zero till, herbicide and } \\
100 \% \text { fertilizers } \\
\text { application) }\end{array}$ & 27.11 & 28.11 & 27.61 & 118.75 & 120.95 & 119.85 & 169.30 & 173.82 & 171.56 & 171.73 & 175.63 & 172.77 \\
\hline $\begin{array}{l}\text { T}_{4:} \text { Improved method -3 } \\
\text { (Minimum tillage, } \\
\text { herbicide and } 75 \% \\
\text { fertilizers application) }\end{array}$ & 27.15 & 28.15 & 27.65 & 115.65 & 117.85 & 116.75 & 163.55 & 172.05 & 167.80 & 167.30 & 175.93 & 169.68 \\
\hline $\begin{array}{l}\text { T}_{5} \text { : Improved method }-4 \\
\text { (Minimum tillage, } \\
\text { herbicide and } 100 \% \\
\text { fertilizers application) }\end{array}$ & 29.13 & 30.13 & 29.63 & 121.85 & 123.95 & 122.90 & 173.43 & 176.88 & 175.15 & 175.20 & 181.23 & 176.04 \\
\hline S. Em. \pm & 0.51 & 0.51 & 0.50 & 1.04 & 1.41 & 1.22 & 1.07 & 1.20 & 1.14 & 1.05 & 1.21 & 1.13 \\
\hline C.D. $(P=0.05)$ & 1.57 & 1.57 & 1.56 & 3.19 & 4.36 & 3.77 & 3.30 & 3.71 & 3.51 & 3.22 & 3.72 & 3.47 \\
\hline
\end{tabular}


Table.2 Total dry matter production $\left(\mathrm{g}_{\text {plant }}{ }^{-1}\right)$ at different growth stages of maize as influenced by improved production technology in rice-maize cropping system

\begin{tabular}{|c|c|c|c|c|c|c|c|c|c|c|c|c|}
\hline \multirow[t]{2}{*}{ Treatments } & \multicolumn{3}{|c|}{30 DAS } & \multicolumn{3}{|c|}{60 DAS } & \multicolumn{3}{|c|}{90 DAS } & \multicolumn{3}{|c|}{ At harvest } \\
\hline & 2016-17 & 2017-18 & Pooled & 2016-17 & 2017-18 & Pooled & 2016-17 & 2017-18 & Pooled & 2016-17 & 2017-18 & Pooled \\
\hline $\begin{array}{l}T_{1} \text { : Farmers method of } \\
\text { cultivation }\end{array}$ & 10.5 & 10.6 & 10.5 & 82.7 & 87.2 & 85.0 & 257.1 & 258.7 & 257.9 & 279.9 & 283.5 & 281.7 \\
\hline $\begin{array}{l}T_{2:} \text { Improved method -1 (Zero } \\
\text { till, herbicide and } 75 \% \\
\text { fertilizers application) }\end{array}$ & 12.5 & 12.8 & 12.6 & 97.5 & 102.4 & 99.9 & 274.5 & 274.5 & 274.5 & 296.4 & 299.6 & 298.0 \\
\hline $\begin{array}{l}T_{3:} \text { Improved method -2 (Zero } \\
\text { till, herbicide and } 100 \% \\
\text { fertilizers application) }\end{array}$ & 15.1 & 15.5 & 15.3 & 105.9 & 110.7 & 108.3 & 280.8 & 284.4 & 282.6 & 304.9 & 308.8 & 306.9 \\
\hline $\begin{array}{l}T_{4:} \text { Improved method }-3 \\
\text { (Minimum tillage, herbicide } \\
\text { and } 75 \% \text { fertilizers } \\
\text { application) }\end{array}$ & 14.3 & 14.7 & 14.5 & 102.5 & 107.4 & 105.0 & 279.8 & 284.0 & 281.9 & 296.4 & 300.0 & 298.2 \\
\hline $\begin{array}{l}\mathrm{T}_{5}: \text { Improved method }-4 \\
\text { (Minimum tillage, } \\
\text { herbicide and } 100 \% \\
\text { fertilizers application) }\end{array}$ & 16.3 & 17.2 & 16.7 & 113.8 & 117.2 & 115.5 & 296.0 & 299.3 & 297.6 & 317.5 & 320.6 & 319.0 \\
\hline S. Em. \pm & 0.3 & 0.2 & 0.2 & 0.6 & 1.3 & 0.8 & 1.0 & 1.8 & 0.9 & 1.7 & 1.7 & 1.7 \\
\hline C.D. $(P=0.05)$ & 1.0 & 0.6 & 0.7 & 1.8 & 3.9 & 2.4 & 3.0 & 5.5 & 2.7 & 5.1 & 5.1 & 5.1 \\
\hline
\end{tabular}


Table.3 Yield components of maize as influenced by improved production technology in rice-maize cropping system

\begin{tabular}{|c|c|c|c|c|c|c|c|c|c|c|c|c|}
\hline \multirow[t]{2}{*}{ Treatments } & \multicolumn{3}{|c|}{ No. of cobs plant ${ }^{-1}$} & \multicolumn{3}{|c|}{ Cob length $(\mathrm{cm})$} & \multicolumn{3}{|c|}{ No. of grain plant ${ }^{-1}$} & \multicolumn{3}{|c|}{ Test weight (g) } \\
\hline & 2016-17 & 7 2017-18 & Pooled & 2016-17 & 2017-18 & Pooled & 2016-17 & 2017-18 & Pooled & 2016-17 & 2017-18 & Pooled \\
\hline $\mathbf{T}_{1:}$ Farmers method of cultivation & 1.2 & 1.1 & 1.2 & 16.1 & 15.7 & 15.9 & 353.5 & 347.2 & 350.5 & 28.3 & 27.8 & 28.0 \\
\hline $\begin{array}{l}T_{2:} \text { Improved method }-1 \text { (Zero } \\
\text { till, herbicide and } 75 \% \\
\text { fertilizers application }\end{array}$ & 1.3 & 1.5 & 1.4 & 17.4 & 17.3 & 17.3 & 371.0 & 373.5 & 372.3 & 30.3 & 30.6 & 30.4 \\
\hline $\begin{array}{l}\text { T}_{3:} \text { Improved method }-2 \text { (Zero } \\
\text { till, herbicide and } 100 \% \\
\text { fertilizers application) }\end{array}$ & 1.6 & 1.7 & 1.7 & 18.4 & 18.8 & 18.6 & 412.0 & 415.4 & 414.3 & 36.3 & 36.6 & 36.4 \\
\hline $\begin{array}{l}\text { T}_{4:} \text { Improved method }-3 \\
\text { (Minimum tillage, herbicide } \\
\text { and } 75 \% \text { fertilizers application) }\end{array}$ & 1.3 & 1.6 & 1.5 & 17.9 & 18.3 & 18.1 & 373.0 & 378.0 & 375.0 & 30.5 & 30.4 & 30.2 \\
\hline $\begin{array}{l}T_{5}: \text { Improved method }-4 \\
\text { (Minimum tillage, herbicide } \\
\text { and } 100 \% \text { fertilizers } \\
\text { application) }\end{array}$ & 1.8 & 1.9 & 1.8 & 19.2 & 19.6 & 19.4 & 429.5 & 431.4 & 429.5 & 38.3 & 38.6 & 38.4 \\
\hline S. Em. \pm & 0.1 & 0.1 & 0.2 & 0.2 & 0.3 & 0.2 & 1.2 & 1.3 & 1.2 & 0.1 & 0.1 & 0.1 \\
\hline C.D. $(P=0.05)$ & 0.2 & 0.2 & 0.2 & 0.6 & 0.7 & 0.6 & 3.6 & 4.0 & 3.6 & 0.3 & 0.4 & 0.2 \\
\hline
\end{tabular}


Table.4 Grain yield, stover yield and harvest index of maize as influenced by improved production technology in rice-maize cropping system

\begin{tabular}{|c|c|c|c|c|c|c|c|c|c|}
\hline \multirow[t]{2}{*}{ Treatments } & \multicolumn{3}{|c|}{ Grain yield (kg ha $\left.{ }^{-1}\right)$} & \multicolumn{3}{|c|}{ Stover yield (kg ha $\left.{ }^{-1}\right)$} & \multicolumn{3}{|c|}{ Harvest index (\%) } \\
\hline & 2016-17 & 2017-18 & Pooled & 2016-17 & 2017-18 & Pooled & 2016-17 & 2017-18 & Pooled \\
\hline $\mathbf{T}_{1:}$ Farmers method of cultivation & 5841 & 5838 & 5840 & 6846 & 7358 & 7102 & 0.46 & 0.44 & 0.45 \\
\hline $\begin{array}{l}T_{2:} \text { Improved method }-1 \text { (Zero till, herbicide } \\
\text { and } 75 \% \text { fertilizers application) }\end{array}$ & 6272 & 6326 & 6299 & 7536 & 7846 & 7691 & 0.45 & 0.45 & 0.45 \\
\hline $\begin{array}{l}\mathbf{T}_{3:} \text { Improved method }-2 \text { (Zero till, herbicide } \\
\text { and } \\
100 \% \text { fertilizers application) }\end{array}$ & 7456 & 7633 & 7544 & 7586 & 9153 & 8369 & 0.48 & 0.45 & 0.48 \\
\hline $\begin{array}{l}T_{4:} \text { Improved method -3 (Minimum tillage, } \\
\text { herbicide and } 75 \% \text { fertilizers application) }\end{array}$ & 6478 & 6794 & 6636 & 8589 & 8314 & 8451 & 0.43 & 0.45 & 0.44 \\
\hline $\begin{array}{l}T_{5}: \text { Improved method }-4 \text { (Minimum tillage, } \\
\text { herbicide and } 100 \% \text { fertilizers application) }\end{array}$ & 7675 & 7687 & 7681 & 8695 & 9207 & 8951 & 0.47 & 0.46 & 0.46 \\
\hline S. Em. \pm & 83 & 25 & 49 & 48 & 25 & 31 & 0.003 & 0.001 & 0.002 \\
\hline C.D. $(P=0.05)$ & 257 & 76 & 151 & 147 & 76 & 97 & NS & NS & NS \\
\hline
\end{tabular}


In rabi season of 2016-17 and 2017-18. At 90 DAS, taller plants were noticed in improved method-4 treatment in rabi season of 2016-17 and 2017-18 ( $\mathrm{T}_{5}: 173.43$ and $176.88 \mathrm{~cm}$, respectively) followed by improved method-2 $\left(\mathrm{T}_{3}: 169.30\right.$ and $173.82 \mathrm{~cm}$, respectively) over farmer method of cultivation $\left(\mathrm{T}_{1}: 150.81\right.$ and $154.32 \mathrm{~cm}$, respectively). Pooled data over two year were significantly differed with respect to plant height. Higher plant was recorded with improved method -4 treatment $\left(\mathrm{T}_{5}: 175.15 \mathrm{~cm}\right)$ as compared to farmer method of cultivation $\left(\mathrm{T}_{1}: 152.56 \mathrm{~cm}\right)$. At harvest stage, improved method-4 treatment showed significantly taller plants $\left(\mathrm{T}_{5}: 175.20\right.$ and $181.23 \mathrm{~cm}$, respectively) followed by improved method-2 $\left(\mathrm{T}_{3}: 171.73\right.$ and 175.63 $\mathrm{cm}$, respectively) over farmer method of cultivation $\left(\mathrm{T}_{1}: 155.53\right.$ and $160.28 \mathrm{~cm}$, respectively). Pooled data over two year were significantly differed with respect to plant height. Higher plant was recorded with improved method -4 treatment $\left(\mathrm{T}_{5}: 176.04\right.$ $\mathrm{cm})$ as compared to farmer method of cultivation $\left(\mathrm{T}_{1}: 154.92 \mathrm{~cm}\right)$. Dry matter production is an important pre-requisite for higher yields as it signifies photosynthetic ability of the crop and also indicates other synthetic processes during developmental sequences. Higher dry matter accumulation and distribution was obtained in improved method-4 treatment (319.0 $\mathrm{g} \mathrm{plant}^{-1}$ ) followed by improved method-2 ( $\left.\mathrm{T}_{3}: 306.9 \mathrm{~g} \mathrm{plant}^{-1}\right)$ over farmer method of cultivation $\left(\mathrm{T}_{1}: 281.7 \mathrm{~g}\right.$ plant $\left.^{-1}\right)$. The higher grain yield in improved method-4 was attributed to maximum yield component viz., number of cobs plant ${ }^{-1}$ (1.8), cob length $(19.4 \mathrm{~cm})$, number of grains plant ${ }^{-1}$ $\left(429.58\right.$ plant $\left.^{-1}\right)$ and test weight $(38.4 \mathrm{~g})$ compared to the farmer method of cultivation. Similar results were obtained by Regar et al., (2010) in chickpea. Higher number of productive tillers and plant height due to nutrient management and minimum tillage practices were also reported by Sinha et al., (2011).Pooled data of two years significantly differed and higher grain yield were noticed in improved method-4 ( $\left.\mathrm{T}_{5}: 7681 \mathrm{~kg} \mathrm{ha}^{-1}\right)$ and it was on par with improved method-2 $\left(\mathrm{T}_{3}\right.$ : $7544 \mathrm{~kg} \mathrm{ha}^{-1}$ ) followed by improved method-3 $\left(\mathrm{T}_{4}: 6636 \mathrm{~kg} \mathrm{ha}^{-1}\right)$ over farmer method of cultivation $\left(\mathrm{T}_{1}: 5840 \mathrm{~kg} \mathrm{ha}^{-1}\right)$. The magnitude of improvement in grain yield of maize by improved method-4 was to the tune of 31.52 per cent over farmer method of cultivation. Similar trend also observed with straw yield of maize. Rajashekarappa et al., (2014) also observed 15-54 per cent improvement in maize yield with moisture conservation practices compared to control. In-situ moisture conservation practices significantly increased the grain and stover yield of sorghum reported as by Rao et al., (2010). The higher grain yield in improved method-4 was attributed to maximum yield component viz., number of cobs plant ${ }^{-1}$ (1.8), cob length $(19.4 \mathrm{~cm})$, number of grains plant ${ }^{-1}(429.58$ plant $\left.^{-1}\right)$ and test weight (38.4 g) compared to the farmer method of cultivation. Similar results were obtained by Regar et al., (2010) in chickpea.

\section{References}

Praharaj, C. S., 2013, Managing precious water through need based microirrigation in a long duration pigeonpea under Indian Plains. In International Conference on Policies for Water and Food Security, Cairo, Egypt June 24-26, 2013, ICARDA, FAO, IFAD, IDRC, CRDI and ARC. Pp. 4.

Praharaj, C. S., Singh, U., Singh S. S., Singh N. P. and Shivay Y. S., 2014, Supplementary and lifesaving irrigation for enhancing pulses production, productivity and water use efficiency in India. Indian J. Agron., 61: 249-261.

Rajashekarappa, K. S., Basavarajappa, B. E. and Puttaiah, M., 2014, Effect of different organic mulches and in-situ green manuring on soil properties, yield 
and economics of maize in dry zone of Karnataka. Green Fmg., 5(1): 61-64.

Rao, S.S., Regar, P.L. and Singh, Y.V., 2010, In-situ rainwater conservation practices in sorghum (Sorghum bicolor) under rainfed conditions in arid regions. Indian J. Soil Conserv., 38(2): 105-110.

Regar, P. L., RAO, S.S. and Joshi, N.L., 2010, Effect of In-situ rain water conservation practices on productivity of chickpea (Cicer arietinum) in the rainfed condition of arid Rajasthan, India. Indian J. Soil Conserv., 38(2): 111-115.

Sinha, B. L., Chauhan, S. K. and Pradhan, M. K., 2011, Effect of tillage and nitrogen on growth and yield of pearl millet under rainfed conditions, Indian J. Soil Conserv., 39(3): 220-225.

\section{How to cite this article:}

Mallareddy, B.K. Desai and Koppalkar, B.G. 2019. Development of Improved Production Technology for Existing Rice-Maize Cropping System in Tungabhadra Command Area. Int.J.Curr.Microbiol.App.Sci. 8(02): 1310-1317. doi: https://doi.org/10.20546/ijcmas.2019.802.153 